\title{
Stress caused by social interaction and its effect on susceptibility to Aeromonas hydrophila infection in rainbow trout Salmo gairdneri
}

\author{
Gabriele Peters ${ }^{1}$, M. Faisal ${ }^{2}$, T. Lang ${ }^{1}$, Iman Ahmed ${ }^{2}$ \\ ${ }^{1}$ Institut für Hydrobiologie und Fischereiwissenschaft der Universität Hamburg, Olbersweg 24, D-2000 Hamburg, Federal \\ Republic of Germany \\ ${ }^{2}$ Faculty of Veterinary Medicine, University of Alexandria, Egypt
}

\begin{abstract}
Juvenile rainbow trout were exposed simultanously to social stress and to infection by the opportunistic ubiquitous bacterium Aeromonas hydrophila. Social interaction between randomly chosen pairs was permitted for $11 \mathrm{~h}$ consecutively. After the first hour the bacteria were either added to the water or were injected intramuscularly. As an indication of the stress syndrome, subordinate fishes showed enhanced ventilation frequency, elevated plasma glucose level, and increased leucocyte volume. In subordinates the pathogens spread to more organs and were found in greater numbers than in the dominant fishes, independent of the mode of bacterial application.
\end{abstract}

\section{INTRODUCTION}

Under artificial conditions of captivity, such as those encountered in aquaculture, fishes are exposed to a multitude of stressors. Among the important stressinducing factors are those with strong psychological components that cause fright, excitement and discomfort (Schreck 1981). Stress may be induced by such activities as handling, transport, and weighing (Mazeaud et al. 1977, Strange et al. 1977). Moreover, crowding at high densities also produces a variety of stimuli that cause stress (Strange et al. 1978). Social interactions, such as battles for rank, can become stressors if subordinate fish cannot escape certain threatening behavior of dominant ones (Erickson 1967 , Noakes \& Leatherland 1977, Ejike \& Schreck 1980, Peters et al. 1980).

Stressors cause disturbances to homeostasis, which are typically manifested by a number of physiological reactions (Gronow 1974, Peters 1979). First, there is an increase in the amount of catecholamine and corticoid hormones released into the blood, which are responsible for a series of secondary reactions, including alterations of carbohydrate metabolism (Donaldson 1981, Mazeaud \& Mazeaud 1981). In a previous report (Peters \& Schwarzer 1985), we described the degeneration of pronephric and splenic leucocytes together with lymphocytopenia and neutrophilia in the peripheral blood of socially stressed rainbow trout. Further, studies done on other fishes exposed to other stressors revealed impaired function of the immunocompetent cells (Ellsaesser \& Clem 1986, Ralph et al. 1987). Pickering \& Duston (1983) observed an increased susceptibility to pathogens after artificial administration of cortisol.

Although rainbow trout are commercially important fishes in Europe and North America, and although they are well known to be highly aggressive, little is known about the physiological and immunological effects of fighting. Thus we were interested in the question of how rainbow trout would react to simultaneous exposure to stress and to facultative pathogenic bacteria. In our experiments, social conflict resulting from threat by a dominant cohort served as the stressor (Peters et al. 1980). Ventilation frequency, plasma glucose level, and leucocrit were used as stress indicators (Wedemeyer 1972). The infectious pathogen was the opportunistic ubiquitous bacterium Aeromonas hydrophila which was used at a concentration expected in commercial culture facilities (Schubert 1967, Heuschmann-Brunner 1978).

\section{MATERIAL AND METHODS}

A total of 80 juvenile rainbow trout Salmo gairdneri Rich., $20.6 \pm 0.7 \mathrm{~cm}$ (mean $\pm \mathrm{SD}$ ) long and weighing $97.4 \pm 4.3 \mathrm{~g}$, from a Northern German pond culture 
facility were used. For a $3 \mathrm{wk}$ adaptation period they were kept together in a flow-through system (flow rate $0.5 \mathrm{I} \mathrm{min}^{-1}, 7.8 \mathrm{mg} \mathrm{O} \mathrm{I}^{-1}$, temperature $17 \pm 1^{\circ} \mathrm{C}$ ). Then they were separated in aquaria partitioned by dark perforated plastic barriers.

In the first experiment (Expt 1), 12 pairs of fish were brought together by removing the partition (S; Fig. 1) after $7 \mathrm{~d}$ of separation. Battles for rank began immediately. The water flow was interrupted for $1 \mathrm{~h}$ to inoculate the water with 18-h-old cultures of Aeromonas hydrophila (dark bar on time scale; Fig. 1). Six aquaria received $10^{3}$ bacteria $\mathrm{ml}^{-1} ; 6$ others received $10^{5} \mathrm{ml}^{-1}$. The experiment was terminated 10 h later. For controls, 8 pairs were treated in the same way, except for exposure to bacteria.

In the second experiment (Expl 2) the fish were isolated for $4 \mathrm{~d}$. Then they were injected intramuscularly (i.m.) with $0.1 \mathrm{ml}$ aliquots of the bacterial cultures, $1 \mathrm{~h}$ after removing the partitions. Six pairs received

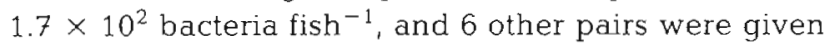
$2.3 \times 10^{4}$ bacteria fish $^{-1}$. The experiment was concluded $10 \mathrm{~h}$ later. As controls, 8 pairs were treated in the same way, but injected with physiological saline $(0.85 \% \mathrm{NaCl})$.

Behavior was observed during the experiments. Dominant fishes were designated $\alpha$, and subordinate fishes $\beta$. The ventilation frequency (VF) was determined at 30 min or $1 \mathrm{~h}$ intervals by counting opercular movements for $1 \mathrm{~min}$. Fishes then were anaesthetized in $200 \mathrm{mg} \mathrm{l}^{-1}$ of MS 222 (Sandoz), weighed, and measured. Blood samples were taken by puncture of the bulbus arteriosus. Blood glucose was measured by the hexokinase glucose-6-phosphate method (Bergmeyer et al. 1974). The leucocrit was determined by the standard micro-method (McLeay \& Gordon 1977).

The bacteria used for the experiment were Aeromonas hydrophila hydrophila, isolated from diseased trout and identified biochemically (Bakteriologisches Institut der Tierärztlichen Hochschule, Hannover, FRG).

The following nutrient media were used.

Nutrient agar: $10 \mathrm{~g}$ glucose, $10 \mathrm{~g}$ peptone from casein, 5 g yeast extract, $7 \mathrm{~g} \mathrm{NaCl}$, and $12 \mathrm{~g}$ agar were added to $1 \mathrm{l}$ of distilled water; $\mathrm{pH}$ was 7.4 . The mixture was boiled and then autoclaved at $121^{\circ} \mathrm{C}$ for $15 \mathrm{~min}$. Occasionally, commercially prepared Merckoplate R (Merck) nutrient agar plates were used.

Nutrient broth: $1 \mathrm{~g}$ glucose, $10 \mathrm{~g}$ peptone from casein, 5 g yeast extract and $7 \mathrm{~g} \mathrm{NaCl}$ were added to $1 \mathrm{l}$ distilled water: $\mathrm{pH}$ was 7.4

Merckoplate $R$ Prolacin Agar (Merck, Darmstadt. FRG) (Bromthymol-blue lactose casein agar) was used for the bacteria counts

Pseudomonad aeromonad select agar (GSP agar according to Kielwein) with penicillin and Pimaricin $R$,
Merck: $10 \mathrm{~g} \mathrm{Na}-(\mathrm{L}+)$ glutamate, $20 \mathrm{gl}^{-1}$ soluble starch, $20 \mathrm{~g}$ potassium dehydrogenphosphate, $0.5 \mathrm{~g} \mathrm{I}^{-1}$ $\mathrm{MgSO}_{4}, 0.36 \mathrm{~g} \mathrm{l}^{-1}$ phenol red, and $12 \mathrm{~g} \mathrm{l}^{-1}$ agar agar.

For $\mathrm{LD}_{50}$ determinations, Aeromonas hydrophila suspensions of $10^{-1}$ to $10^{-8}$ were prepared by dilution in sterile broth cultures. Five fishes were inoculated intramuscularly with $0.1 \mathrm{ml}$ of suspension at each dilution level. The fishes were kept in $50 \mathrm{l}$ glass aquaria The $\mathrm{LD}_{50}$, calculated according to the methods of Reed \& Muench (1938), proved to be $1.9 \times 10^{3}$ bacteria/ $4 \mathrm{~d}$.

Samples of spleen, liver, kidney, and peripheral blood were obtained under aseptic conditions immediately after the body cavity was opened to detect the invasion and spread of the pathogen. Samples were streaked on GSP agar plates and incubated at $28^{\circ} \mathrm{C}$ for 3 to 4 d. Blood samples from Expt 2 werc diluted $10^{-1}$ to $10^{-5}$ in nutrient broth, spread on prolacin agar, and incubated at $28^{\circ} \mathrm{C}$ for 3 to $4 \mathrm{~d}$ to determine the number of colonies per $\mathrm{ml}$.

For statistical evaluation, the mean $(\bar{x})$ and the standard deviation (SD) were calculated, and the data compared using the U-test (Mann \& Whitney 1974) or the $\chi^{2}$-test (Kendall \& Stuart 1968).

\section{RESULTS}

\section{Behavior}

In all tanks, rank order fights usually began after pairs of trout were brought together by removing the partition. The conflicts consisted of threatening postures, frontal attacks, and biting. In most cases, a few attacks were sufficient to establish hierarchy; the subordinate $(\beta)$ fishes immediately turned dark and became passive. From the beginning, aggressiveness of the dominant $(\alpha)$ fishes was variable. The number of attacks ranged from 1 to $50 \mathrm{~min}^{-1}$. In a few cases dominance was achieved by one of the individuals even though there was no obvious fighting. The subordinate partners of highly aggressive $\alpha$-fishes became rapidly exhausted. Trying to escape attacks, they hid in the corners or pressed themselves against the bottom of the aquarium. Occasionally, subordinates held their bodies vertically, the head toward the surface or the bottom. Their increasing exhaustion was manifested by decreased reaction to the patrolling partner. At the end of the experiment, all fishes could be recognized by their behavior as $\alpha$ or $\beta$.

In Expt 1, the dominant fishes were more aggressive and the subordinate individuals showed a more pronounced manifestation of fear than those in Expt 2 , presumably due to the longer isolation period before the beginning of the experiment.

The $\alpha$-fishes infected with bacteria showed greater 
aggressiveness and infected $\beta$-fishes were more rapidly exhausted than their respective counterparts in the non-infected groups.

\section{Ventilation irequency}

The mean ventilation frequency (VF) of the fish in both experiments increased immediately after the first confrontation of the partners ( $S_{;}$Fig. 1). About 1 h later, $\mathrm{VF}$ began to slow down. In $\alpha$-fishes, it returned to the resting value within 4 to $5 \mathrm{~h}$. The subordinates $(\beta)$ however, retained an elevated mean VF during the entire course of the experiments. Even when the dominant individual showed no aggressive behavior, the VF of the subordinate individual remained high. Evidently the presence of the $\alpha$-fish was sufficient to stress the defeated individual.

Respiration of infected subordinates (lower part of Fig. 1), was much higher than that of the uninfected subordinates.

Respiratory activity was essentially similar in Expt 1 (Fig. 1) and Expt 2 (Table 1) except that the VF of the $\beta$ fishes returned to the baseline much more rapidly in Expt 2

\section{Blood glucose}

Mean blood sugar levels of the stressed fishes showed a significant increase after $11 \mathrm{~h}$ of social interaction $(p<0.001)$. There was wide individual variation. In some cases, hyperglycemia with blood sugar concentrations up to 10 times the normal level were noted, while in others, the normal mean was hardly exceeded (Fig. 2)

In Expt 2, in which fishes were exposed to a lower stress level as they had been isolated beforehand for only $4 \mathrm{~d}$, the increase of blood glucose in $\beta$-fish was far less than that in Expt 1 (Table 1).

Among the infected fish, the same trends were observed. In the subordinates the mean plasma glucose level was higher than in the dominants $(p<0.01)$. In Expt 2 the difference between the blood sugar content of $\alpha$-and $\beta$-fish was reduced (Fig. 2 , Table 1 ).
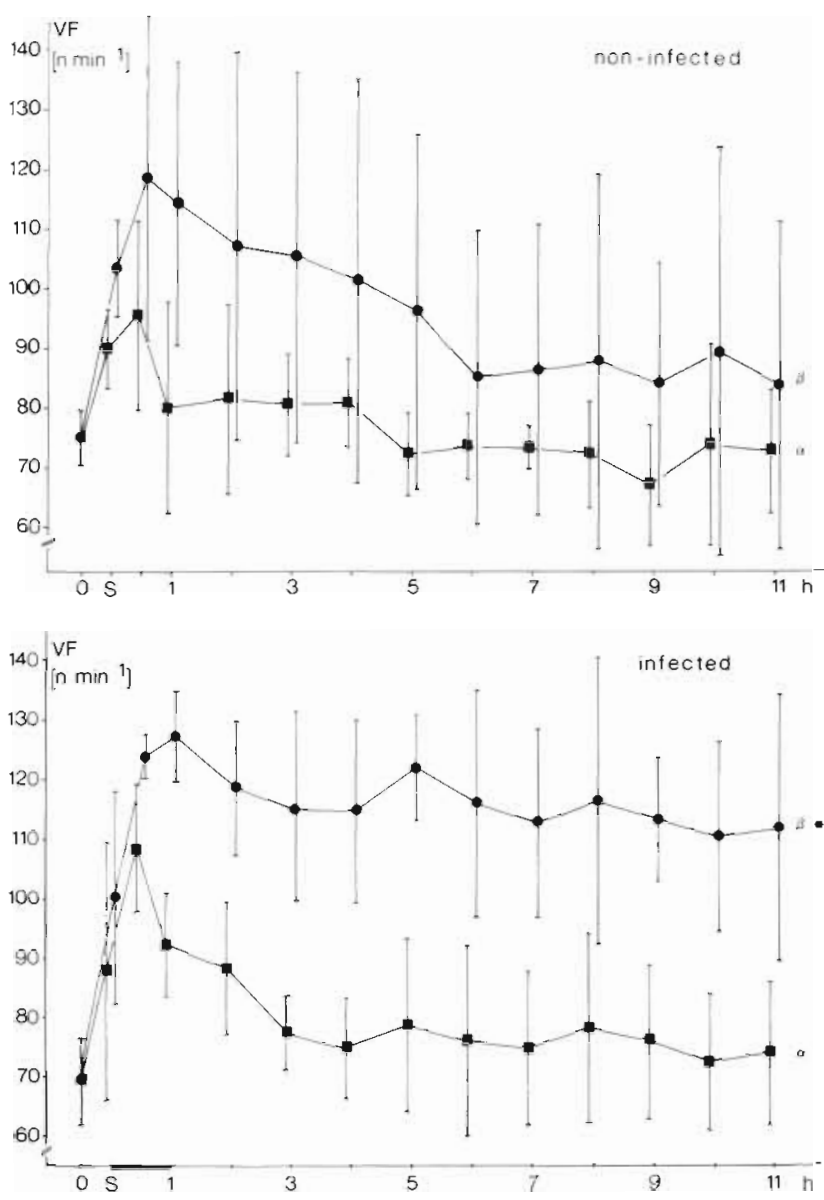

Fig. 1. Salmo gairdneri. Expt 1. Ventilation frequency (VF) $\mathrm{min}^{-1}$ of rainbow trout. Above: non-infected fish; below: after application of Aeromonas hydrophila to the water for $1 \mathrm{~h}$. (a) $\overline{\mathrm{x}}$ of the isolated fish; $(\square) \bar{x}$ of dominant $(\alpha)$ fish; $(\bullet) \bar{x}$ of subordinate $(\beta)$ fish; vertical lines: $S D$; $S$ : time of removing the partitions; thick line on abscissa: application time; $n$ : counts of 6 fish in each group. ${ }^{*} p<0.01$

Table 1. Salmo gairdneri. Expt 2. Ventilation frequency (VF), blood glucose level and leucocrit in rainbow trout after $11 \mathrm{~h}$ of social interaction and intramuscular injection of bacteria

\begin{tabular}{|c|c|c|c|c|c|c|c|c|c|c|c|c|}
\hline & \multicolumn{6}{|c|}{ Non-infected fish } & \multicolumn{6}{|c|}{ Infected fish } \\
\hline & \multicolumn{3}{|c|}{ Dominant } & \multicolumn{3}{|c|}{ Subordinate } & \multicolumn{3}{|c|}{ Dominant } & \multicolumn{3}{|c|}{ Subordinate } \\
\hline & $\overline{\mathrm{x}}$ & $\mathrm{SD}$ & $n$ & $\bar{x}$ & $\mathrm{SD}$ & $n$ & $\overline{\mathrm{x}}$ & $\mathrm{SD}$ & $n$ & $\bar{x}$ & SD & $n$ \\
\hline$V F\left(n \min ^{-1}\right)$ & 75.5 & 15.9 & 4 & 80.0 & 18.7 & 6 & 88.8 & 16.2 & 4 & 102.3 & 14.4 & 6 \\
\hline Blood glucose (mmol $\left.1^{-1}\right)$ & 2.38 & 0.99 & 8 & 3.84 & $2.55^{\circ}$ & 8 & 1.68 & 1.02 & 12 & 2.90 & $1.72^{\circ}$ & 12 \\
\hline Leucocrit $(\%)$ & 3.00 & 2.10 & 8 & 4.90 & 3.00 & 8 & 1.70 & 1.00 & 12 & 6.80 & $3.90^{\circ}$ & 12 \\
\hline$\cdot p<0.01$ & & & & & & & & & & & & \\
\hline
\end{tabular}



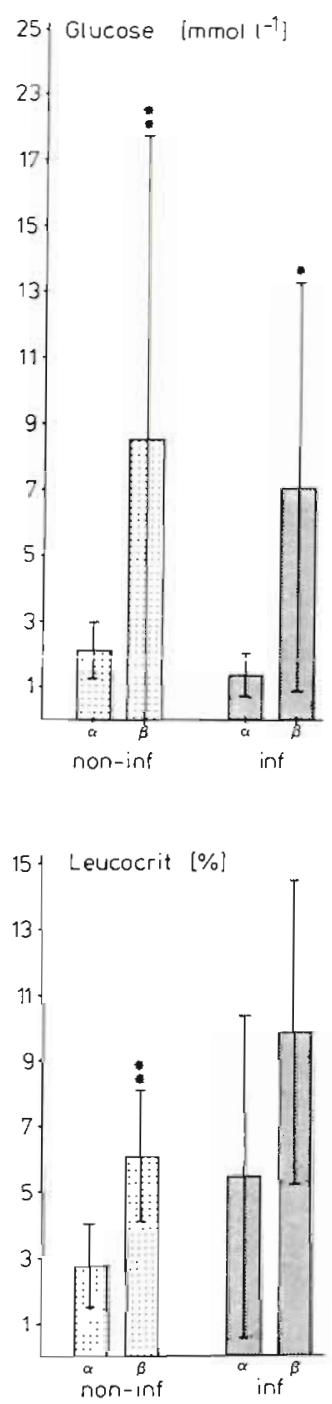

Fig. 3. Salmo gairdneri. Expt 1. Volume of white blood cells (leucocrit) in rainbow trout after $11 \mathrm{~h}$ of social conflicts and waterborne infection of bacteria. For further explanations, see Fig. 2

\section{The leucocrit}

In the non-infected pairs, the dominant trout had an average leucocyte volume of about $3 \%$. In Expt 1 this value was doubled in stressed fish $(p<0.001)$ (Fig. 3 ). In Expt 2 the difference between $\alpha$ and $\beta$ was not statistically significant.
Application of Aeromonas hydrophila resulted in an additional increase in the mean leucocyte volume. In $\alpha$ fishes from Expt 1 the leucocrit was twice, and in $\beta$ fishes 3 times, the value found in non-infected controls (Fig. 3). In Expt 2, the stressed fish also showed elevated leucocrit values (Table 1, $p<0.01$ ).

\section{Spread of bacteria}

At the end of the $11 \mathrm{~h}$ of social interaction, and $10 \mathrm{~h}$ after bacterial application, no gross signs of disease were obvious in the infected fish. However, the bacteria had spread through the internal organs to a greater extent in subordinate than in dominant fishes (Table 2). The difference in number of positive reisolates be tween stressed and unstressed fishes was statistically significant in both experiments $(p<0.01)$. In addition, in Expt 2 the number of bacteria in the blood in the majority of stressed trout had increased substantially (Fig. 4). In 6 out of 12 blood samples of $\beta$-fishes the

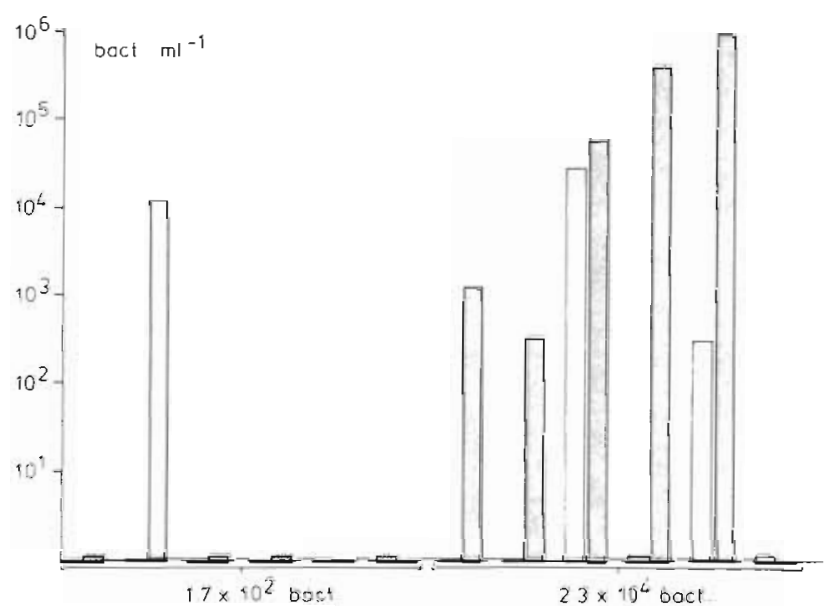

Fig. 4. Salmo gairdneri. Expt 2. Concentrations of reisolated bacteria Aeromonas hydrophila from the blood of 24 rainbow trout after $11 \mathrm{~h}$ of social stress and i.m. application of bacteria at 2 levels. Thick lines on abscissa: reisolates of one pair of fish; light-stippled bars: reisolates from $\alpha$; dark-stippled bars: reisolates from $\beta$

Table 2. Salmo gairdneri. Spreading of Aeromonas hydrophila in rainbow trout after $11 \mathrm{~h}$ of social interaction. Values are number of fish from which bacteria could be reisolated. b: blood; s: spleen; l: liver; $\mathrm{k}$ : kidney

\begin{tabular}{|c|c|c|c|c|c|c|c|c|}
\hline & \multicolumn{4}{|c|}{ Dominant } & \multicolumn{4}{|c|}{ Subordinate } \\
\hline & $\mathrm{b}$ & s & l & $\mathrm{k}$ & $b$ & s & 1 & $\mathrm{k}$ \\
\hline \multicolumn{9}{|l|}{ Infection via water } \\
\hline Low conc. $1.3-1.7 \times 10^{3}(n=6)$ & 2 & 0 & 0 & 0 & 4 & 0 & 0 & 0 \\
\hline High conc. $4.9-5.6 \times 10^{5}(n=6)$ & 6 & 2 & 0 & 0 & 6 & 6 & 6 & 3 \\
\hline \multicolumn{9}{|l|}{ Intramuscular infection } \\
\hline Low conc $1.7 \times 10^{2}(n=6)$ & 1 & 3 & 0 & 0 & 4 & 4 & 0 & 0 \\
\hline High conc $2.3 \times 10^{4}(n=6)$ & 4 & 3 & 1 & 1 & 5 & 5 & 3 & 3 \\
\hline
\end{tabular}


bacterial counts ranged between $3.2 \times 10^{2} \mathrm{ml}^{-1}$ and $9.0 \times 10^{5} \mathrm{ml}^{-1}$. In the unstressed fishes, only 2 out of 12 blood samples showed high numbers of bacteria (between $3.0 \times 10^{2} \mathrm{ml}^{-1}$ and $2.7 \times 10^{4} \mathrm{ml}^{-1}$ ). There was no statistically significant difference in the spread of bacteria between Expts 1 and 2 .

Independent of the mode of bacterial application, $\alpha$ and $\beta$-fish blood and spleen seemed to be invaded more intensely by the pathogens than were liver and kidney tissue.

\section{DISCUSSION}

When pairs of juvenile rainbow trout were exposed to social stress, which they could not avoid, the subordinate fish displayed typical stress reactions. The attempts of these fish to fight or to flee were accompanied by an increase in respiration rate. They also showed elevated plasma glucose level and an increase in white blood cell volume. In this respect they react like European eels Anguilla anguilla L. attacked by aggressive partners, which display a classical General Adaptation Syndrome (Selye 1952), including an increase in plasma cortisol, glucose, and lactate concentrations and a decrease in hepatic glycogen content (Peters et al. 1980, Peters \& Hong 1985). Ejike \& Schreck (1980) also found that social subordination of rainbow trout is correlated with physiological changes in the blood. Hormonal stress reactions together with secondary metabolite consequences have also been observed among Xiphophorus helleri defeated in battles for rank (Hannes 1981)

The effects described as non-specific reactions can also be induced by other emotional stressors. For example, hyperglycemia can be caused by handling, captivity, exertion, and pursuit (summarized by Barton 1987).

For the stress reactions described in this study, values for stressed fishes show much greater variability than those for unstressed individuals. Peters et al. (1980) obtained similar findings with eels. The increased variability between individuals is likely due to differences in the intensity of the external threat, that is, the changing strength of the stressor. It may also be attributed to genetic or adaptational differences in the condition of the individuals. However, we consider this variability primarily to be a manifestation of a disturbed physiological balance in the body. The irritation interferes with the feedback mechanism that normally maintains homeostasis.

From experiments conducted with European eels and coho salmon Oncorhynchus kisutch, it was obvious that dominant fishes resemble unstressed controls in all physiological parameters measured (Ejike \& Schreck 1980, Peters et al. 1980). The VF data in this study demonstrated that dominant trout were stressed only at the beginning of the conflict. Shortly afterward, their respiration rates returned to normal, reflecting security and control of the situation.

The tissue and blood samples obtained from subordinate trout that had been experimentally infected were more frequently contaminated with bacteria than those of the dominant partners. In addition, the numbers of bacteria that could be reisolated were higher. This result was observed regardless of the method used to apply the bacteria. The pathogens in both experiments were able to overcome the complex defense mechanisms of the stressed fish more easily than those of the unstressed ones. All the bacterial concentrations used led to a more severe invasion of the subordinate fish than of the dominant ones. In spite of the observed bacteraemia in dominant fish infected with the higher Aeromonas hydrophila concentration in Expt 1, the bacteria did not invade the hemopoietic tissues in the way they did in subordinates.

Observations by McLeay \& Gordon (1977), Tomasso et al. (1983), and Wedemeyer et al. (1983), as well as those reported here, include an increase in the leucocrit of stressed fish. The greater volume of the leucocytes results from an increase in number and a hypertrophy of granulocytes (Klinger 1985). In earlier investigations of rainbow trout exposed to social stress for several days, it was found that neutrophilic granulocytes and their precursor cells developed into large macrophagelike cells. Their morphological appearance would suggest that after a transient stage of stimulation these cells progressively degenerate (Peters \& Schwarzer 1985). Thus, a reduction in their functional capacity might finally be expected, affecting not only the phagocytic destruction of pathogens, but also the presentation of antigen to the antibody-producing lymphocytes.

In stressed fishes, lymphocytes also undergo obvious alterations. Lymphocytopenia is often observed (Pickford et al. 1971, Esch \& Hazen 1980, Peters et al. 1980, Pickering et al. 1982). Furthermore, the remaining lymphocytes seem handicapped in their function. Elsaesser \& Clem (1986) noted that channel catfish lymphocytes no longer responded to the mitogens LPS and Con $A$ after fish were frightened by handling. Moreover, much fewer of these lymphocytes were surfaceimmunoglobulin-positive than those from undisturbed fish. These findings are supported by those of Barrow (1955), who found antibodies against trypanosomes only in fish dominant in the hierarchy.

As mentioned before, stress-related levels of corticosteroids are presumed to interfere with basic immunological functions of the blood. Bullock \& Stuckey (1975) successfully used corticosteroids to produce overt furunculosis in asymptomatic carrier rainbow 
trout. In similar experiments, McCarthy (1977) was able to bring about a high rate of Aeromonas salmonicida infection in brook trout. Recently, Ralph et al. (1987) examined the in vitro suppression of B cell activity by cortisol applied to Oncorhynchus kisutch. They suggest that the inhibition of a lymphokine-like factor is involved in the kinetics of stress-related immunosuppression.

In this study we show that social subordination causes impairment to the defense mechanisms of rainbow trout. In view of the observed structural alteration of phagocytes expressed in the increased leucocrit in stressed fish, we consider the functional disturbances of these cells to be of major significance within the context of the host-pathogen interaction.

Acknowledgements. We thank Prof. Dr K. H. Böhm of the Bakteriologisches Institut der Tierärztlichen Hochschule, Hannover, for providing us with the bacteria. We gratefully acknowledge critical comments on the manuscript by Prof. Dr E. L. Cooper, UCLA School of Medicine and Science, Los Angeles, USA. We also thank Mrs G. Thedens and Dipl.-Biol. W. Pfeiffer for technical help. The study was supported by Grant No. MFE 0528 from the Bundesministerium für Forschung und Technologie and the Deutsche Akademische Austauschdienst. The authors are responsible for the contents. The paper includes parts of the Ph. D. thesis of T. Lang.

\section{LITERATURE CITED}

Barrow, J. H. (1955). Social behaviour in freshwater fish and its effect on resistance to trypanosomes. Proc. natl Acad. Sci. U.S.A. $41,676-679$

Barton, B. A. (1987). Interrenal and metabolic responses to stress and their modifying factors in juvenile salmonid fishes. Thesis, Oregon State University

Bergmeyer, H. U., Bernt, E., Schmidt, F., Stork, H. (1974). DGlucose, Bestimmung mit Hexokinase und Glucose-6phosphat-Dehydrogenase. In: Bergmeyer, H. U. (ed.) Methoden der enzymatischen Analyse Vol. 2. Weinheim, Verlag Chemie, p. 1241-1246

Bullock, G., Stuckey, H. M. (1975). Aeromonas salmonicida detection in asymptomatically infected trouts. Progve Fish Cult. 37: 237-239

Donaldson, E. M. (1981). The pituitary-interrenal axis as an indicator of stress in fish. In: Pickering, A. D. (ed.) Stress and fish. Academic Press, London, p. 11-47

Ejike, C., Schreck, B. (1980). Stress and social hierarchy rank. in coho salmon. Trans. Am. Fish. Soc. 109, 423-426

Ellsaesser, C. F., Clem, L. W. (1986). Hematological and immunological changes in channel catfish stressed by handling and transport. J. Fish Biol. 28, 511-521

Erickson, J. G. (1967). Social hierarchy, territoriality and stress reactions in sunfish. Physiol. Zool. 40, 40-48

Esch, G. W. Hazen, T C. (1980). Stress and body condition in a population of Largemouth Bass: implication for RedSore-Dosease. Trans. Am. Fish. Soc. 109: 532-536

Gronow, G. (1974). Über die Anwendung des an Säugetieren erarbeiteten Begriffes 'Stress' auf Knochenfische. Zool. Anz. 192: 316-331

Hannes, R. P. (1981). Wechselwirkung zwischen Steroidhormonen und dem Aggressionsverhalten männlicher
Schwertträger (Xiphophorus helleri). Diss. FB Biologie, Univ. Hamburg

Heuschmann-Brunner, G. (1978). Die Aeromonaden der 'Hydrophila-punctata-Gruppe' bei Süßwasserfischen. Arch. Hydrobiol. 83: 99-125

Kendall, M. G., Stuart, A. (1968). The advanced theory of statistics. Vol. 3. Design and analysis, and time series. 2nd ed. Griffin, p. 35-38

Klinger, H. (1985). Grundlagen und Anwendung hämatologischer und morphologischer Methoden zur Diagnose von Streß in der Fischhaltung unter besonderer Berücksichtigung des Aals (Anguilla anguilla L.). Diss. FB Biologie, Univ. Hamburg

Mann, H. B., Whitney, D. R. (1974). On a test of whether one of two random variables is stochastically larger than the other. Ann. Math. Statist. 18: 50-60

Mazeaud, M. M., Mazeaud, F. (1981). Adrenergic responses to stress in fish. In: Pickering, A. D. (ed.) Stress and fish. Academic Press, London, p. 49-75

Mazeaud, M. M., Mazeaud, F., Donaldson, E. H. (1977). Stress resulting from handling in fish: primary and secondary effects. Trans. Am. Fish. Soc. 106, 201-212

McCarthy, D. H. (1977). Some ecological aspects of the bacterial fish pathogen Aeromonas salmonicida. Aquatic Microbiology Soc. Appl. Bacteriol. Symp. 6: 299-324

McLeay, D. J., Gordon, M. R. (1977). Leucocrit: a simple hematological technique for measuring acute stress in salmonid fish, including stressful concentrations of pulpmill effluent. J. Fish. Res. Bd Can. 34: 1264-2175

Noakes, D. L. G., Leatherland, J. F. (1977). Social dominance and interrenal cell activity in rainbow trout, Salmo gairdneri (Pisces, Salmonidae). Env. Biol. Fish. 2: 131-136

Peters, G. (1979). Zur Interpretation des Begriffs 'Stress' beim Fisch. Fisch und Tierschutz 7: 25-32

Peters, G., Hong, L. Q. (1985). Gill structure and blood electrolyte levels of European eels under stress. In: Ellis, A. E. (ed.) Fish and Shellfish Pathology Academic Press, London, p. 183-196

Peters, G., Schwarzer, R. (1985). Changes in hemopoietic tissue of rainbow trout under influence of stress. Dis. aquat Org. $1: 1-10$

Peters, G., Delventhal, H., Klinger, H. (1980). Physiological and morphological effects of social stress in the eel (Anguilla anguilla L.). Arch. FischWiss. 30: 157-180

Pickering, A. D., Duston, J. (1983). Administration of cortisol to brown trout, Salmo trutta L., and its effects on the susceptibility to Saprolegnia infection and furunculosis. J. Fish. Biol. 23: 163-175

Pickering, A. D., Pottinger, T. G., Christie, P. (1982). Recovery of the brown trout, Salmo trutta L. from acute handling stress, a time course study. J. Fish Biol. 20; 229-244

Pickford, G. E., Srivastava, A. K., Slicher, A. M., Pang, P. K. T (1971). The stress response in the abundance of circulating leucocytes in the Killifish Fundulus heteroclitus. 3. The role of the adrenal cortex and a concluding discussion of the leucocyte stress syndrome. J. exp. Zool. 177: 109-117

Ralph, A. T., Maule, A. G., Schreck, C. B., Kaattari, S. L. (1987). Cortisol mediated suppression of Salmonid lymphocyte responses in vitro. Dev. Comp. Immunol. 11: 565-576

Reed. L. J., Muench, H. (1938). A simple method of estimating fifty percent end point. Am. J. Hyg. 7: 493-497

Schreck, C. B. (1981). Stress and compensation in teleostean fishes: responses to social and physical factors. In: Pickering, A. D. (ed.) Stress and fish. Academic Press, London, p. 295-321

Schubert, R. H. W. (1967). Das Vorkommen der Aeromonaden in oberirdischen Gewässern. Arch. Hyg. 150: 688-708 
Selye, H. (1952). Das Allgemeine Adaptionssyndrom und die Adaptionskrankheiten. Wien. Klin. Wochenschr. 64: $781-783$

Strange, R. J., Schreck, C. B., Ewing, R. D. (1978). Cortisol concentration in confined juvenile chinook salmon (Oncorhynchus tshawytscha). Trans. Am. Fish. Soc. 107. 812-819

Strange, R. J., Schreck, C. B., Golden, J. T. (1977). Corticoid stress response to handling and temperature in salmonids. Trans. Am. Fish. Soc. 106: 213-218
Tomasso, J. R., Simco, B. A., Davis, K. B. (1983). Circulating corticosteroid and leucocyte dynamics in channel catfish during net confinement. Texas J. Sci. 35: 83-88

Wedemeyer, G. A. (1972). Some physiological consequences of handling stress in juvenile coho salmon (Oncorhynchus kisutch) and steelhead trout (Salmo gairdneri). J. Fish. Res. Bd Can. 29: 1780-1783

Wedemeyer, G. A., Gould, R. W., Yasutake, W. T. (1983) Some potentials and limits of the leucocrit test as a fish health assessment method. J. Fish. Biol. 23: 711-716

Editorial responsibility: Managing Editor; accepted for printing on April 18, 1988 